\title{
EFEKTIVITAS PEMBELAJARAN ILMU TASAWUF DALAM MENINGKATKAN RELIGIUSITAS MAHASISWA \\ (Studi pada Mahasiswa Fakultas Ushuluddin, Adab dan Dakwah Institut Agama Islam Negeri [IAIN] Pontianak Tahun 2014)
}

\author{
Muh. Gitosaroso
}

\begin{abstract}
ABSTRAK
Saat ini kehidupan mahasiswa sedang dihadapkan pada budaya pragmatisme dalam menjalani perkuliahan. Fenomena ini ditandai dengan perilaku dimana mahasiswa kuliah hanya sekedar memperoleh nilai. Padahal idealnya, perolehan nilai tersebut harus dibarengi dengan penguasaan berbagai kompetensi yang disyaratkan pada setiap mata kuliah. Penelitian ini dilakukan sebagai sebuah ikhtiar untuk mengatasi, atau minimal mengurangi fenomena tersebut. Peneliti berkeinginan agar proses pembelajaran yang peneliti lakukan dapat membekas dalam diri mahasiswa. Karena mata kuliah IImu Tasawuf erat kaitannya dengan kehidupan religius, maka peneliti berkeinginan yang kuat agar proses perkuliahan yang peneliti berikan pada mahasiswa dapat meningkatkan kualitas religiusitas mereka. Penelitian ini menggunakan model Pre-Experimental dengan bentuk One Group PretsesPosttest Design. Pengumpulan data dilakukan dengan menggunakan alat berupa angket. Uji efektivitas pembelajaran ilmu tasawuf dalam rangka meningkatkan religiusitas mahasiswa dilakukan dengan menggunakan uji t berpasangan (paired sample $t$ test). Hasil penelitian menunjukkan bahwa religiusitas mahasiswa mengalami peningkatan setelah mendapat perlakuan dengan pembelajaran ilmu tasawuf, yaitu dari yang awalnya $56 \%$ berada pada kategori kurang baik meningkat menjadi $47 \%$ berada pada kategori baik. Uji efektivitas diperoleh nilai t hitung (t statistik) sebesar 41.009 dengan signifikansi 0.00 , karena nilai signifikansi $<0.05$, maka $\mathrm{H}_{0}$ ditolak, artinya: terdapat perbedaan yang signifikan antara tingkat religiusitas siswa sebelum dan sesudah menerima perlakuan dengan pembelajaran ilmu tasawuf.
\end{abstract}

Kata Kunci: religiusitas, pembelajaran, tasawuf

\section{A. Latar Belakang}

Bangsa Indonesia adalah bangsa yang mempunyai budi pekerti luhur. Bangsa yang hidupnya senantiasa bersandar pada tata nilai berbagai agama dan kepercayaan yang tumbuh dan berkembang di Indonesia. Akibatnya, bangsa Indonesia menjadi bangsa yang rakyatnya mempunyai tingkat religiusitas 
yang tinggi. Bahkan, nailai-nilai religiusitas tersebut telah menjadi karakter dan watak bangsa Indonesia.

Akan tetapi, realitas kehidupan telah berbicara lain. Akibat dari pengaruh budaya barat yang liberal, kini telah merapuhkan kehidupan religius masyarakat Indonesia. Sebagai contoh nyatanya, selama ini, bangsa Indonesia yang dikenal sebagai bangsa agamis, bangsa yang berbudi pekerti luhur, bangsa yang masyarakatnya selalu santun dalam berperilaku, lembut dan ramah dalam bertutur sapa, musyawarah dan mufakat dalam menyelesaikan masalah, menghormati dan toleran terhadap perbedaan, gotong royong dalam urusan bersama, jujur dalam komitmen, dan berbagai sebutan lainnya, akhir-akhir ini masayarakat kita menunjukkan perubahan ke arah yang negatif. Berbagai fenomena sosial yang muncul akhir-akhir ini cukup mengkhawatirkan. Fenomena kekerasan dalam menyelesaikan masalah menjadi hal yang umum. Pemaksaan kehendak terjadi hampir pada setiap level masyarakat. Penekanan dan pemaksaan kehendak satu kelompok terhadap kelompok lain dianggap biasa. Bahkan, berbagai perilaku negatif tersebut, kini telah mewabah dalam dunia pendidikan. Hampir setiap hari kita mendapatkan berita dari media massa terkait dengan perilaku nagitif tersebut, seperti menyontek dalam ujian, tawuran antar sekolah dan kampus, terlibat dalam tindakan kriminal, terjerumus dalam pengaruh obat-obatan terlarang (NARKOBA) dan perilaku-perilaku negatif lainnya.

Situasi seperti diungkapkan tersebut tentu saja tidak boleh terjadi pada mahasiswa IAIN Pontianak. Untuk mengantisipasi agar mahasiswa di IAIN Pontianak tidak terpengaruh oleh fenomena negatif tersebut harus dilakukan upaya yang sistematis. Salah satu upaya yang dapat dilakukan adalah dengan cara mengoptimalkan proses pembelajaran. Terkait dengan hal tersebut, peneliti akan melakukan ihtiar keilmuan dengan cara memaksimalkan pembelajaran pada mata kuliah ilmu tasawuf untuk meningkatkan religiusitas mahasiswa. Dalam rangka memehuni harapan tersebut, penelitian ini dilakukan untuk melihat sejauhmana dampak pembelajaran ilmu tasawuf dalam meningkatkan religiusitas mahasiswa.

\section{B. Masalah Penelitian}

Saat ini kehidupan mahasiswa sedang dihadapkan pada budaya pragmatisme dalam menjalani perkuliahan. Fenomena ini ditandai dengan perilaku dimana mahasiswa kuliah hanya sekedar memperoleh nilai. Padahal idealnya, perolehan nilai tersebut harus dibarengi dengan penguasaan berbagai kompetensi yang disyaratkan pada setiap mata kuliah. Sehingga yang terjadi adalah, banyak 
alumni perguruan tinggi yang memperoleh nilai kumulatif (IPK) tinggi, akan tetapi ketika dihadapkan pada dunia kerja, mereka masih mengalami kebingungan. Mahasiswa yang nilai akhir perkuliahannya tinggi, akan tetapi perilaku kesehariannya tidak menunjukkan karakter yang baik.

Penelitian ini dilakukan sebagai sebuah intiar untuk mengatasi, atau minimal mengurangi fenomena tersebut. Peneliti berkeinginan agar proses pembelajaran yang peneliti lakukan dapat membekas dalam diri mahasiswa. Karena mata kuliah IImu tasawuf eratkaitannya dengan kehidupan religius, maka peneliti berkeinginan yang kuat agar proses perkuliahan yang peneliti berikan pada mahasiswa dapat meningkatkan kualitas religiusitas mereka.

Berangkat dari masalah tersebut, maka masalah utama yang akan diungkap melalui penelitian ini adalah: "Bagaimanakah Efektifitas Pembelajaran IImu Tasawuf terhadap Peningkatan Religiusitas Mahasiswa Fakultas Ushuluddin, Adab dan Dakwah IAIN Pontianak?"

Masalah utama penelitian tersebut, selanjutnya dijabarkan dalam masalah khusus penelitian sebagai berikut:

1. Bagaimanakah tingkat religiusitas mahasiswa sebelum mendapatkan pembelajaran ilmu tasawuf?
2. Bagaimanakah tingkat religiusitas mahasiswa sesudah mendapatkan pembelajaran ilmu tasawuf ?

3. Bagaimanakah efektifitas pembelajaran ilmu tasawuf dalam meningkatkan religiusitas mahasiswa?

\section{Tinjauan Teoritis}

Konstruk teori yang digunakan dalam penelitian ini adalah teori religiusitas dalam perspektif Islam. Dalam konteks Islam, menurut Ancok dan Suroso (2011: 80) dimensi keyakinan dapat disejajarkan dengan aqidah, dimensi praktik agama disejajarkan dengan syariah dan dimensi konsekuensial dengan akhlak. Ungkapan ini jika diperbandingkan dengan konsep keberislaman (Dînu al-Islâm) seperti diungkapkan dalam hadis Nabi Muhammad SAW yang diriwayatkan oleh Umar Ibn Khaththab RA ketika datang seorang laki-laki datang kepada Nabi SAW dan bertanya tentang iman, Islam dan insan, lalu beliu menjelaskan kepadanya, kemudia bersabda: "Tadi adalah Malaikat Jibril, dia datang untuk mengajarkan tentang agama kepada kalian" (HR. Muslim. No.8). Dalam kajian psikologi, religiusitas sering disebut dengan komitmen beragama, yang menurut Anshari (1983: 77) komitmen beragama dalam konteks Islam mencakup tiga hal, yaitu iman, Islam dan insan. Sementara itu, pembahasan tentang insan, menurut 
Hikmawati (2008: 57) sering disamakan dengan akhlak, yaitu tingkah laku dan budi pekerti yang baik menurut ajaran agama Islam.

Dengan mengacu pada beberapa pendapat di atas, dalam penelitian ini, religiusitas dimaknai dalam perspektif Islam, yaitu kualitas personal dalam menginternalisasi dan mengaplikasikan keberislamannya, yang menyangkut tiga dimensi utama, yaitu keyakinan (aqidah), praktik kegamaan (ibadah) dan konsekuensial (akhlak).

\section{1) Dimensi Aqidah}

Dimensi keyakinan atau aqidah Islam merujuk pada seberapa tingkat keyakinan muslim terhadap kebenaran ajaran-ajaran agamanya, terutama terhadap ajaran yang bersifat fundamental dan dogmatik. Dimensi aqidah dijabarkan dalam enam sub-aspek dengan indikator masing-masing sebagai berikut:

Aspek Keimanan kepada Allah, dengan indikator: (1) Merasakan kehadiran Allah, (2) Merasa diperhatikan oleh Allah, (3) Bahagia dengan nikmat yang ada, (4) Memiliki cara pandang positif terhadap realitas kehidupan, (5) Tidak goyah dalam menghadapai persoalan hidup, Menumbuhkan kesadaran bahwa dalam menjani hidup manusia penuh dengan godaan, (7) Menyadari bahwa manusia terkadang lemah di hadapan godaan, (8)
Menumbuhkan

kesadaran dan

Membangun komunitas istiqamah.

Aspek Keimanan kepada Malaikat, dengan indikator: (1) Mengimani Wujud Malaikat, (2) Mengimani sifat-sifat malaikat, dan (3) Mengimani tugas-tugas malaikat.

Aspek Keimanan kepada Kitabkitab Allah, dengan indikator: (1) Mengimani bahwa kitab-kitab benar diturunkan oleh Allah, (2) Membenarkan seluruh berita yang benar, seperti berita dalam Al-Quran dan berita pada kitab terdahulu yang belum diselewengkan.

Aspek Keimanan kepada Rasul, dengan indikator: (1) Mengimani bahwa risalah mereka benar-benar dari Allah SWT, (2) Mengimani nama-nama nabi dan rasul sebagaiman dijelaskan dalam AlQuran dan Hadis Nabi Muhamad SAW, (3) membenarkan berita-berita mereka yang sahih riwayatnya, dan (4) Mengamalkan syari'at Nabi Muhammad SAW.

Aspek Keimanan kepada Hari Akhir, dengan indikator: (1) Menyadari bahwa hidup akan berakhir, (2) Mengimani peristiwa-peristiwa setelah kematian, (3) Menghubungkan amal hari ini dengan balasan kelak di akhirat, (4) Mengimani ba'ats, (5) Mengimani hisab, (6) Mengimani surga dan neraka sebagai tempat yang abadi.

Aspek Keimanan kepada Qadha dan Qadar, dengan indikator: Mengimani Taqdir, (2) mengimani bahwa 
apa yang dikehendaki Allah pasti terjadi dan qodrat-Nya meliputi segala sesuatu.

\section{2) Dimensi Ibadah}

Dimensi ibadah merupakan sikap penghambaan seseorang kepada Allah SWT melalui pelaksanaan ibadah mahdhah dan ghoiru mahdhah. Dimensi ini dijabarkan dalam beberapa sub-aspek sebagai berikut:

Aspek Komitmen sebagai Hamba Allah, dengan indikator: (1) Bersemangat melakukan kebaikan, (2) Takut untuk melanggar hukum, (3) Menumbuhkan kesadaran untuk berpacu dengan waktu untuk melakukan amal-amal shaleh, (4) Mengapresiasi nikmat dengan cara mengungkapkannya, (5) Menggunakan nikmat sesuai dengan amanah pemberi nikmat (syukur), (6) Tahu diri dan ingin berbakti, (7) Menjadikan ibadah sebagai tujuan hidup, (8) Optimis bahwa ibadahnya diterima oleh Allah, (9) Berjanji untuk selalu berusaha taat beribadah, (10) Menumbuhkan budaya untuk melapor dan memohon pertolongan Allah, Mengenal waktu-waktu yang mustajab untuk berdo'a.

\section{Aspek Mengucapkan Dua Kalimat} Syahadat, dengan indikator: (1) Berikrar, bahwa tidak ada Tuhan selain Allah, dan (2) Bersumpah menerima akibat dan risiko apapun dalam mengamalkan Risalah Nabi Muhammad SAW.
Aspek Mendirikan Shalat, dengan indikator: (1) Membiasakan diri selalu dalam keadaan suci, (2) Melaksanakan shalat wajib, dan (3) Melaksanakan shalat sunnah.

Aspek Menjalankan Ibadah Puasa, dengan indikator: (1) Melaksanakan puasa wajib, dan (2) Melaksanakan puasa sunnah.

Aspek Membayar Zakat, dengan indikator: (1) membiasakan diri bershadaqah, dan (2) Membayar zakat fitrah.

Aspek Menunaikan Ibadah Haji, dengan indikator: Melaksanakan ibadah haji.

\section{3) Dimensi Akhlak}

Dimensi akhlak merujuk pada seberapa tingkatan seorang muslim berperilaku dimotivasi oleh ajaran-ajaran agamanya, yaitu berperilaku dalam balutan al-akhlak al-karimah. Dimensi ini dijabarkan dalam beberapa sub-aspek sebagai berikut:

Aspek Akhlak terhadap Rasulullah, dengan indikator: (1) Mencintai Rasulullah secara tulus dengan mengikuti sunnahnya, dan (2) Menjadikan Rasulullah sebagai idola, suri tauladan dalam kehidupan.

Aspek Akhlak terhadap Orangtua, dengan indikator: (1) Berbuat baik kepada ibu bapak dengan sebaik-baiknya, dan (2) 
Memelihara hubungan silaturrahim dengan keluarga.

Aspek Akhlak terhadap Diri Sendiri, dengan indikator: (1) Memelihara kesucian diri, (2) Menyadari bahwa manusia memiliki sifat imitasi, (3) Meniru tipologi manusia an'amta alaihim (orang mendapat nikmat), (4) Menghindari tipologi almaghdubi 'alaihim (orang yang mendapat murka), dan al-Dhâllîn (orang yang sesat), (5) Berkomitmen untuk bercermin dan hidup bersama orang-orang dengan tipolologi an'amta 'alaihim, (6) Membangun komunitas istiqamah.

Aspek Akhlak terhadap Keluarga, dengan indikator: (1) Membina rasa cinta dan kasih sayang dalam kehidupan keluarga, dan (2) Saling menunaikan kewajiban untuk memperoleh hak.

Aspek Akhlak terhadap Tetangga, dengan indikator: (1) Berbagi dengan sesama, dan (2) Memelihara hubungan silaturrahim dengan tetangga.

Aspek Akhlak terhadap Masyarakat dan Lingkungan, dengan indikator: (1) Bersosialisasi dengan baik, (2) Sadar dan memelihara kelestarian lingkungan hidup, dan (3) Sayang pada sesama makhluk hidup.

Sementara itu, pembelajaran ilmu tasawuf dalam penelitian ini diartikan sebagai sebuah kegiatan yang dialakukan oleh dosen untuk menciptakan situasi agar mahasiswa melakukan aktivitas belajar ilmu tasawuf, dimana di dalamnya mencakup pengetahuan, praktik dan latihan diri melalui cinta yang dalam dan ibadah untuk mengembalikan diri kepada jalan Allah SWT.

\section{Metode Penelitian}

Penelitian ini menggunakan model Pre-Experimental dengan bentuk One Group Pretses-Posttest Design. Dalam desain ini, responden, yang terdiri dari empat kelas, dilakukan prates, kemudian diberikan perlakuan dengan pembelajaran ilmu tasawuf, kemudian dilalkukan pascates. Pengumpulan data dilakukan dengan menggunakan alat berupa angket. Uji efektivitas pembelajaran ilmu tasawuf dalam rangka meningkatkan religiusitas mahasiswa dilakukan dengan menggunakan ujian $t$ berpasangan (paired sample $t$ test).

Sebelum dilakukan uji efektivitas, terlebih dahulu dilakukan analisis deskriptif dengan rumus rata - rata untuk memperoleh gambaran religiusitas mahasiswa sebelum dan sesudah diberikan perlakuan. Untuk menentukan nilai rata-rata dari masing-masing responden terhadap item-item pernyataan, maka dilakukan dengan cara menjumlah nilai tanggapan responden peritem / perindikator dibagi dengan masing-masing jumlah item atau indikator dalam tiap variabel. Sementara untuk mempermudah penilaian maka dibuat kategori penilaian, 
dimana menurut Riduwan (2005) perhitungan analisis statistik deskriptif terhadap tanggapan responden dilakukan menggunakan rumus sebagai berikut :

a) Rata-rata Total Skor=

$$
\bar{x}=\frac{\sum_{i=1}^{n} x_{i}}{n}
$$

b) Total Skor Terendah $\left(\mathrm{X}_{\text {Min }}\right)$ =

Skor Terendah $\mathrm{x}$ Jumlah Item

c) Total Skor Tertinggi $\left(\mathrm{X}_{\mathrm{Max}}\right)$ =

Skor Tertinggi $x$ Jumlah Item

d) Rentang Total Skor

$$
=R=X_{\text {Max }}-X_{\text {Min }}
$$

e) Rentang Katagori

$$
\frac{R}{\text { Skor Tertinggi }}
$$

f) Jumlah Katagori= =

$$
\frac{R}{\operatorname{Re} n \tan g \text { Katagori }}
$$

Uji Efektivitas Pembelajaran IImu Tasawuf untuk meningkatkan religiusitas mahasiswa dilakukan dengan menganalisis skor pretest dan posttest responden. Uji efektivitas tersebut dilakukan dengan menggunakan uji $t$ dengan prosedur sebagai berikut:

\section{a. Uji Normalitas Data}

Uji normalitas pada penelitian ini dilakukan dengan menggunakan uji Kolmogorov Smirnov, dengan ketentuan, data dikatakan mengikuti distribusi normal jika nilai signifikansi $>$ alpha $(\alpha=0.05)$.

\section{b. Uji Homogenitas (Kesamaan Varians)}

Uji kesamaan varians dalam penelitian ini dilakukan dengan menggunakan uji Levene's atau Levene's Test. Kriteria penerimaan dan penolakan hipotesis nol $\left(\mathrm{H}_{0}\right)$ adalah: Jika probabilitas signifikansi > alpha $(0,05)$ maka $\mathrm{H}_{0}$ ditolak, artinya: Varians total skor siswa tidak homogen, dan sebaliknya jika signifikansi $<0.05$, maka $\mathrm{H}_{0}$ diterima, artinya: Varians total skor siswa relatif homogen.

\section{c. Uji Efektivitas Pembelajaran dalam Meningkatkan Religiusitas Mahasiswa}

Uji t dua sampel yang saling bebas (independent $t$ test) digunakan untuk membandingkan apakah kedua kelompok data memiliki kesamaan atau berbeda dengan tujuan untuk membandingkan karakteristik individu di dalam sekelompok data dengan rata-ratanya. Ketentuan dalam melakukan uji t adalah: jika t hitung $>\mathrm{t}$ tabel atau probabilitas signifikansi < tingkat alpha, maka tolak Hipotesis Nol $\left(\mathrm{H}_{0}\right)$.

Hipotesis penelitian berbunyi: "Pembelajaran IImu Tasawuf efektif untuk meningkatkan religiusita mahasiswa". Adapun hipotesis statistiknya adalah sebagai berikut:

$$
\begin{aligned}
& \mathrm{H}_{0}: \mu_{\text {pretest }}=\mu_{\text {posttest }} \\
& \mathrm{H}_{1}: \mu_{\text {pretest }}>\mu_{\text {posttest }}
\end{aligned}
$$


Untuk mengetahui apakah Pembelajaran IImu Tasawuf efektif dalam meningkatkan religiusitas mahasiswa, dapat dilihat dari rata-rata, simpangan baku (standard deviasi) dan standar error pada uji statistik deskriptif antara prestes dan postes. Semua pengujian sebagaimana disebutkan di atas dilakukan dengan menggunakan Package Software SPSS 17.00 for Windows.

\section{E. Hasil Penelitian}

Penelitian ini telah berhasil mengungkap tiga data yang dapat digunakan untuk menjawab pertanyaan penelitian, yaitu terkait dengan gambaran religiusitas mahasiswa sebelum diberikan perlakuan, gambaran religiusitas mahasiswa sesudah diberikan perlakuan dan efektivitas perlakuan yang berupa pembelajaran ilmu tasawuf dalam meningkatkan religiusitas mahasiswa.

\section{Gambaran Religiusitas Mahasiswa Sebelum Diberikan Perlakuan}

$$
\text { Hasil penelitian menunjukkan }
$$

bahwa profil religiusitas mahasiswa Fakultas Ushuluddin, Adab dan Dakwah IAIN Pontianak sebelum diberikan perlakuan dengan pembelajaran ilmu tasawuf secara umum berada pada kategori kurang baik (56\%). Secara lebih rinci profil religiusitas mahasiswa Fakultas Ushuluddin, Adab dan Dakwah IAIN
Pontianak sebelum diberikan perlakuan dengan pembelajaran ilmu tasawuf dapat dilihat pada tabel berikut:

Tabel 4.1

Gambaran Umum Religiusitas Mahasiswa Fakultas Ushuluddin, Adab dan Dakwah IAIN Pontianak Sebelum Diberikan Perlakuan

\begin{tabular}{|l|c|c|c|}
\hline Kriteria & Interval & Frekuensi & Persentase \\
\hline Sangat Baik & $589-724$ & 6 & 6 \\
\hline Baik & $454-588$ & 28 & 28 \\
\hline Kurang Baik & $318-453$ & 56 & 56 \\
\hline Tidak Baik & $181-317$ & 0 & 0 \\
\hline Jumlah & 100 & 100 & \\
\hline
\end{tabular}

Dengan persentase seperti tampak pada tabel tersebut, dapat disimpulkan bahwa mayoritas mahasiswa Fakultas Ushuluddin, Adab dan Dakwah IAIN Pontianak sebelum mengikuti pembelajaran ilmu tasawuf memiliki tingkat religiusitas yang kurang baik. Hanya $28 \%$ yang berkatagori baik dan $6 \%$ dengan katagori sangat baik. Dengan demikian, sebelum diberikan pembelajaran tasawuf, sebagian besar mahasiswa masih memerlukan peningkatan religiusitas mereka.

\section{Gambaran Religiusitas Mahasiswa Sesudah Diberikan Perlakuan}

Analisis data religiusitas mahasiswa setelah mendapatkan perlakuan dengan pembelajaran mata kuliah ilmu tasawuf menunjukkan bahwa tingkat religiusitas mahasiswa Fakultas Ushuluddin, Adab dan 
Dakwah IAIN Pontianak sesudah diberikan perlakuan dengan pembelajaran ilmu tasawuf secara umum berada pada kategori baik (47\%). Secara lebih rinci profil religiusitas mahasiswa Fakultas Ushuluddin, Adab dan Dakwah IAIN Pontianak sebelum diberikan perlakuan dengan pembelajaran ilmu tasawuf dapat dilihat pada tabel berikut:

Tabel 4.2

Gambaran Umum Religiusitas Mahasiswa Fakultas Ushuluddin, Adab dan Dakwah IAIN Pontianak Sesudah Diberikan Perlakuan

\begin{tabular}{|l|c|c|c|}
\hline \multicolumn{1}{|c|}{ Kriteria } & Interval & Frekuensi & Persentase \\
\hline Sangat Baik & $589-724$ & 30 & 30 \\
\hline Baik & $454-588$ & 47 & 47 \\
\hline Kurang Baik & $318-453$ & 13 & 13 \\
\hline Tidak Baik & $181-317$ & 0 & 0 \\
\hline \multicolumn{2}{|c|}{ Jumlah } & 100 & 100 \\
\hline
\end{tabular}

Berdasarkan pada tabel tersebut, kita mendapatkan kesimpulan bahwa telah terjadi peningkatan pada tingkat religiuitas mahasiswa setelah mengikuti perlakukan dengan pembelajaran ilmu tasawuf, diamana, jika pada tabel tingkat religiusitas mahasiswa sebelum mendapatkan perlakuan kriteria sangat baik hanya mencapai $6 \%$, maka pada tabel religiusitas pasca perlakuan kriteria sangat baik mencapai $30 \%$. Selanjutnya, pada kriteria baik, dari sebelum perlakuan mencapai $28 \%$, maka setelah perlakuan presentase tersebut meningkat menjadi 47\%.
Sebaliknya, terjadi penurunan pada kriteria kurang baik, yaitu dari praperlakukan sebesar $56 \%$, pasca perlakuan turun menjadi $13 \%$. Dengan demikian, dapat disimpulkan, bahwa religiusitas mahasiswa mengalami peningkatan setelah mereka mendapat perlakuan dengan pembelajaran ilmu tasawuf.

\section{Efektivitas Pembelajaran IImu Tasawuf dalam Meningkatkan Religiusitas Mahasiswa}

Uji efektivitas dalam penelitian ini dilakukan dengan menggunakan analisis uji sampel berpasangan (paired samples $t$ test). Dalam uji tersebut disyaratkan data harus terdistribusi normal dan relative homogeny. Itulah sebabnya, sebelum uji t dilakukan, terlebih dahulu dilakukan uji normalitas dan homogenitas. Uji normalitas pada penelitian ini dilakukan dengan menggunakan uji Kolmogorov Smirnov, dengan ketentuan, data dikatakan mengikuti distribusi normal jika nilai signifikansi $>$ alpha $(\alpha=0.05)$. hasil uji normalitas data dapat dilihat pada tabel berikut:

Tabel 4.3

Tests of Normality

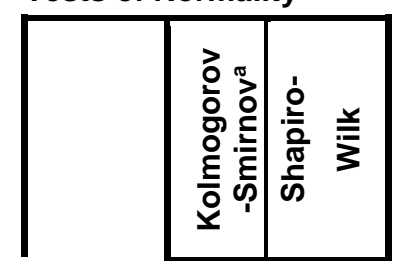




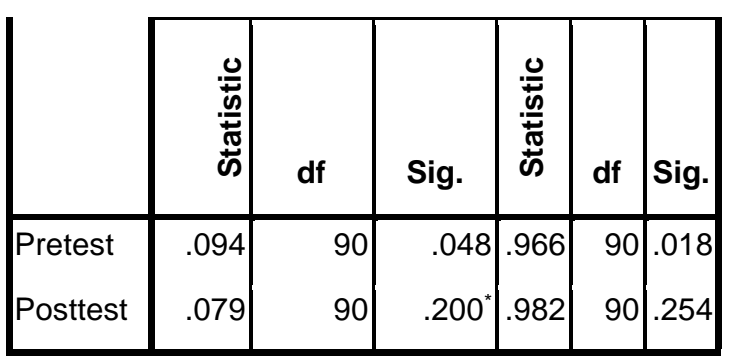

a. Lilliefors Significance Correction

*. This is a lower bound of the true significance.

Berdasarkan pada tabel tersebut, uji normalitas menggunakan uji Kolmogorov Smirnov memiliki nilai signifikansi $<0,05$. Karena nilai signifikansi lebih kecil dari alpha $(\alpha=0.05)$, maka dapat disimpulkan bahwa data tidak memenuhi asumsi distribusi normal. Untuk mengatasi problem pemenuhan asumsi normalitas dalam uji $t$ (t test) dapat dilakukan dengan beberapa jalan, diantaranya transformasi data dan pemeriksaan outlier. Dalam penelitian ini, sebagai tindak lanjutnya dilakukan pemeriksaan outlier dengan teknik BoxPlot (Dan Dan dan ljeoma (2013: 9). Hasil

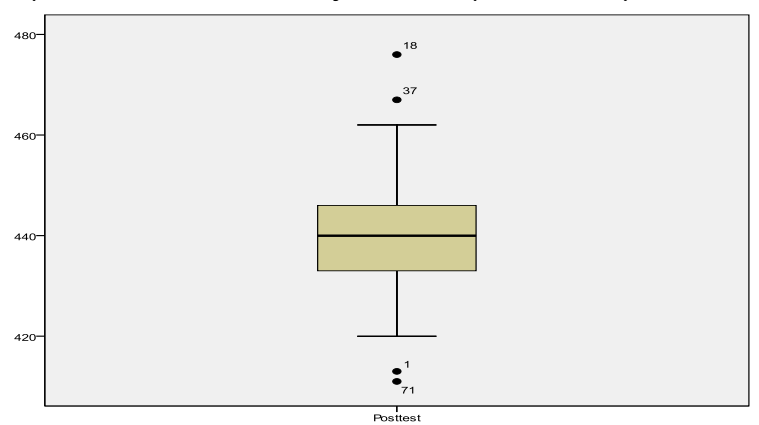

Berdasarkan hasil pemeriksaan outlier pada data yang tidak normal yaitu nilai prosttest, sebagaimana terlihat pada grafik 4.19, diketahui terdapat 4 outlier pada data sebagai berikut: $1,18,37$, dan 71. Tindak lanjut dari terdeteksinya 4 outlier pada data tersebut adalah dilakukan pembuangan outlier. Setelah outlier dikeluarkan dari data, peoses selanjutnya adalah melakukan uji normalitas ulang. Hasil dari proses uji normalitas ulang tersebut, dapat dilihat dalam bentuk tabel 4.7 sebagai berikut:

Tabel 4.4

Tests of Normality

\begin{tabular}{|l|r|r|r|r|r|r|}
\hline \multirow{1}{*}{} & \multicolumn{3}{|c|}{$\begin{array}{c}\text { Kolmogorov- } \\
\text { Smirnova }\end{array}$} & \multicolumn{3}{c|}{ Shapiro-Wilk } \\
\cline { 2 - 7 } & Statistic & df & Sig. & Statistic & df & Sig. \\
\hline Pretest & .095 & 86 & .055 & .970 & 86 & .045 \\
Posttest & .060 & 86 & $.200^{*}$ & .984 & 86 & .343 \\
\hline
\end{tabular}

a. Lilliefors Significance Correction

*. This is a lower bound of the true significance.

Berdasarkan table 4.4 diketahui bahwa semua data telah terdistribusi normal. Hal ini terlihat dari nilai signifikansi yang lebih besar dari nilai alfa $(\alpha=0,05)$. Dengan demikian, maka analisis dapat dilanjutkan, yaitu uji t.

Berdasarkan uji t yang dilakukan dengan menggunakan SPSS 17.00, hasilnya dapat dilihat sebagaimana tabel 4.5 berikut:

Tabel 4.5

Paired Samples Test

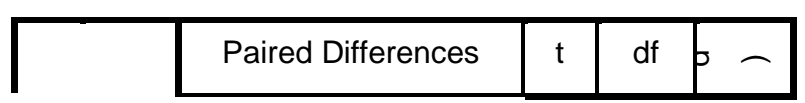




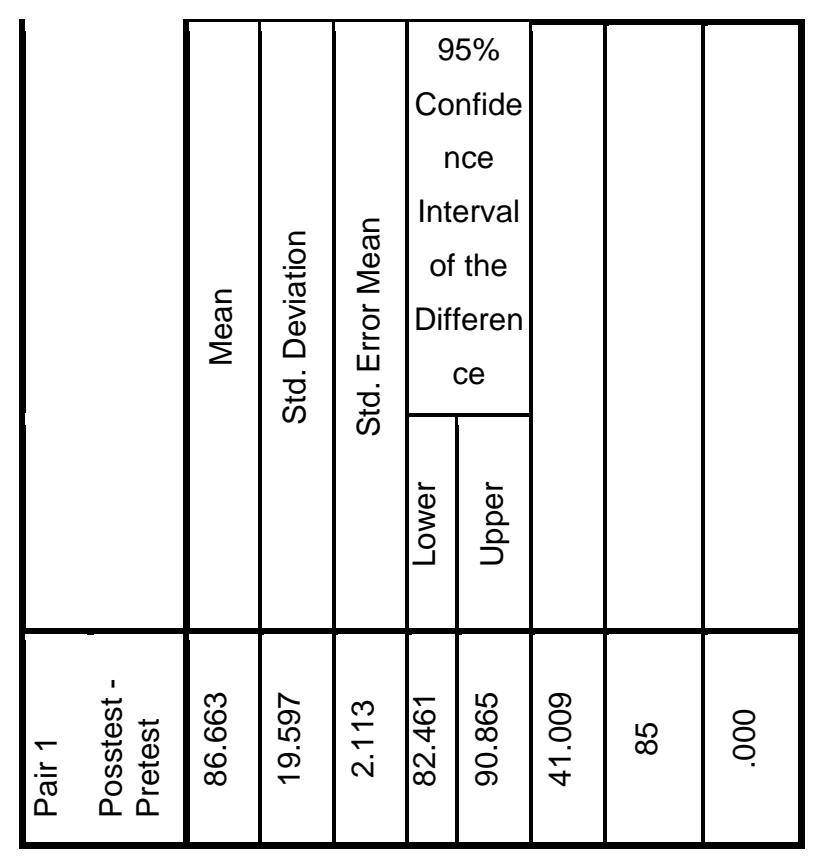

Berdasarkan hasil analisis statistik dengan menggunakan uji t pada Tabel 4 . 5 , dengan asumsi varians sama yang telah dipenuhi, diperoleh nilai t hitung (t statistik) sebesar 41.009 dengan signifikansi 0.00, karena nilai signifikansi $<0.05$, maka $\mathrm{H}_{0}$ ditolak, artinya: terdapat perbedaan yang signifikan antara tingkat religiusitas siswa sebelum dan sesudah menerima perlakuan dengan pembelajaran ilmu tasawuf.

Untuk mengetahui apakah pembelajaran ilmu tasawuf efektif dalam meningkatkan religiusitas mahasiswa, dapat dilihat dari rata-rata, simpangan baku (standar deviasi) dan standar eror pada uji statistik deskriptif sebagai berikut:

Tabel 4.6

Analisis Deskriptif Total Skor Tingkat Religiusitas Mahasiswa sesudah dan sebelum mendapatkan perlakuan

\begin{tabular}{|c|c|c|c|c|}
\hline & Mean & $\mathrm{N}$ & $\begin{array}{c}\text { Std. } \\
\text { Deviation }\end{array}$ & $\begin{array}{l}\text { Std. Error } \\
\text { Mean }\end{array}$ \\
\hline $\begin{array}{l}\tau^{\text {Posstest }} \\
. \overline{\bar{\sigma}} \\
\alpha \text { Pretest }\end{array}$ & $\begin{array}{l}439.44 \\
352.78\end{array}$ & $\begin{array}{l}86 \\
86\end{array}$ & $\begin{array}{r}9.502 \\
18.237\end{array}$ & $\begin{array}{l}1.025 \\
1.967\end{array}$ \\
\hline
\end{tabular}

Berdasarkan hasil perhitungan pada Tabel 4.6, diperoleh rata-rata total skor pretest sebesar 352,78 dengan simpangan baku sebesar 9,237 dan standar error sebesar 1,962, sedangkan rata-rata total posttest adalah sebesar 439,44 dengan simpangan baku sebesar 9.502 dan standar error sebesar 1,025. Dengan demikian dapat disimpulkan bahwa pembelajaran ilmu tasawuf efektif dalam meningkatkan religiusitas mahasiswa Fakultas Ushuluddin, Adab dab Dakwah IAIN Pontianak. Hal ini terbukti bahwa setelah mendapatkan interveni pembelajaran ilmu tasawuf, religiusitas mahasiswa mengalami peningkatan sebesar 86.66 .

\section{F. Pembahasan Hasil Temuan}

Hasil penelitian menunjukkan bahwa religiusitas mahasiswa Fakultas Ushuluddin, Adab dan Dakwah IAIN Pontianak sebelum diberikan perlakuan dengan pembelajaran ilmu tasawuf secara umum berada pada kategori kurang baik (56\%). Dengan capaian religiusitas seperti ini, berarti terjadi hambatan perkembangan fitrah manusia. Dengan terhambatnya perkembangan fitrah ini, maka manusia 
akan keluar dari karakter manusia religius. Menurut Najati (1985: 362) ciri orang yang tidak berkembang fitrahnya adalah sebagai berikut: (1) dalam hal aqidah, mereka tidak beriman kepada aqidah tauhid, kepada para rasul, hari kiamat, hari kebangkitan dan hisab; (2) dalam hal ibadah, dia menyembah kepada selain Allah; (3) dalam hubungan sosial, ia dhalim, suka memusuhi dan menghina orang beriman, gemar mengajak kepada kemungkaran, dan melarang orang berbuat kebajikan; (4) dalam hubungan kekeluargaan, ia senang meutuskan silaturrahmi; (5) dalam aspek moral, ia suka mengingkari janji, berlaku serong, menuruti hawa nafsu, sombong, dan takabur; (6) dalam hal hawa nafsu dan emosional, ia benci dan dengki kepada orang beriman, dan benci kepada karunia Allah yang diberikan kepada orang beriman; dan (7) dalam hal intelektual ia tidak mampu memahami dan berpikir, hatinya tertutup, taqlid buta kepada tradisi dan kepercayaan nenek moyang.

\section{Dalam bahasa yang berbeda,} kondisi rendahnya religiusitas ini menunjukkan bahwa mahasiswa tersebut belum mempunyai komitmen beragama yang baik. Padahal, komitmen bergama yang baik erat kaitannya dengan kualitas kehidupannya pada masa yang akan datang. Hikmawati (Kurnanto, 2014) mengatakan bahwa pembentukan komitmen beragama turut membantu dalam menentukan pilihan dan menuntun tingkah laku individu serta mempengaruhi individu sepanjang sisa hidupnya. Kondisi ini dimungkinkan, karena perkembangan religiusitas erat kaitannya dengan perkembangan berbagai aspek perkembangan lainnya. Penjelasan ini juga senada dengan penjelasan Syamsuddin (2007: 105-110) yang menyatakan bahwa perkembangan perilaku keagamaan (religiusitas) terjadi dalam satu paket dengan perkembangan perilaku sosial dan moral. Bahkan, dijelaskan bahwa perkembangan penghayatan keagamaan sejalan dengan perkembangan moralitas dan erat kaitannya dengan perkembangan intelektual, emosional, dan volisional (konatif). Ketereratan ini dimungkinkan karena secara potensial (fitriah) manusia adalah makhluk sosial (zoon politicon) dan makhluk beragama. Selain itu, dalam sudut pandang Brigtman (Syamsuddin, 2007: 108) hal ini juga merupakan pengakuan atas keberadaan the excistence of great power dan mengakui-Nya sebagai sumber nilai-nilai luhur yang eternal (abadi) yang mengatur tata hidup manusia dan alam semesta raya ini. Bahkan, dilihat dari sisi pengembangan sumber daya manusia, hasil penelitian yang dilakukan oleh Fauzan dan Setiawati (2005), menunjukkan bahwa religiusitas memiliki pengaruh yang signifikan terhadap prestasi kerja PNS yang bekerja di lingkungan Kantor Departemen Agama Kota Malang. 
Dengan keadaan awal seperti diungkap data tersebut, berarti bahwa kualitas tiga dimensi religiusitas mahasiswa, yaitu keimanan, iabadah dan akhlak mereka kurang baik. Padahal, kita ketahui bahwa iman kepada Allah merupakan tonggak utama keberislaman seseorang, yang akan mempengaruhi semua aspek yang lain. Kondisi ini jika tidak segera disikapi dengan baik akan membawa pengaruh yang negatif terhadap perilaku siswa. Hal ini dimungkinkan, karena antara iman dan perilaku mempunyai hubungan timbal balik; iman dapat mempengaruhi perilaku, sebaliknya perilaku juga dapat mempengaruhi fluktuasi iman. Perilaku yang mulia dapat meningkatkan kadar keimanan, karena perilaku itu merupakan cerminan keimanan kepada Allah SWT. Allah SWT befirman: "Sesungguhnya orang-orang yang beriman ialah mereka yang bila disebut nama Allah gemetarlah hati mereka, dan apabila dibacakan ayat-ayat-Nya bertambahlah iman mereka (karenanya), dan hanya kepada Tuhanlah mereka bertawakkal" (QS. Al-Anfal: 2). Salah satu pengaruh Iman kepada Allah, adalah menjauhkan seseorang dari perbuatan maksiat, kerena ketika di dalam hatinya memiliki benteng dan pondasi yang kuat (iman) maka tidak ada satupun yang dapat menyingkirkannya, baik itu dari godaan setan ataupun pengaruh hawa nafsu. Nabi Saw. bersabda: "Tidak berzina orang yang beriman itu, tidak mencuri orang yang beriman itu, dan tidak minum-minuman keras bagi orang yang minum sedang dalam keadaan beriman". (HR. Bukhari dan Muslim).

Shihab (2003, XIII: 265) menjelaskan hakikat iman dalam tafsirnya, yaitu ketika menjelaskan ayat $14-15$ surat Al-Hujarat. Dalam penjelasannya disebutkan bahwa orang yang sempurna imannya adalah orang yang beriman kepada Allah dan mengimani semua sifatsifat-Nya, dan bersaksi bahwa Nabi Muhammad adalah Rasul-Nya dan segala apa yang disampaikannya, kemudian walaupun menghadapi ujian dan bencana yang berat - mereka tidak ragu, dan mereka juga membuktikan kebenaran imannya dengan berjihad, yaitu membela kebenaran dengan mengorbankan jiwa dan raganya di jalan Allah. Dengan kriteria seperti ini, maka jelas bahwa orang yang beriman adalah individu yang mempunyai dampak dalam kehidupan yang positif, yaitu individu yang selalu bermanfaat dalam kehidupan sosialnya. Oleh karena itu, kondisi individu yang menampakkan fenomena rendah imannya harus segera dicarikan solusi dengan memberikan bimbingan yang mampu mendongkrak kualitas iman tersebut.

Perlu diketengahkan di sini, bahwa walaupun iman sangat fungsional dalam kehidupan manusia, akan tetapi dengan iman saja belum cukup. Kualitas iman 
seseorang harus diikuti dengan takwa. Itulah sebabnya, dalam al-Quran kata iman sering kali dirangkai dengan takwa, bahkan jumlahnya lebih dari sepuluh tempat (QS. 2: 103, 2: 278, 3: 102, 5: 35, 5: 65, 7: 96, 8: 29, 9: 119, 33: 70, 39: 10, 47: 36, 57: 28, 59: 18). Dalam ilmu tafsir, biasanya pemasangan satu kata dengan kata lain yang terjadi di banyak tempat (atau berulang-ulang) menunjukkan bahwa dua kata tersebut tidak bisa saling dipisahkan. Demikian juga pemasangan kata iman dan takwa ini, menurut Sutoyo (2006: 72) mengandung makna iman seseorang belum sempurna jika tidak diikuti oleh takwa. Sebaliknya, ketakwaan seseorang tidak ada artinya jika tidak dilandasi oleh iman yang benar. Bahkan dikatakan bahwa takwa adalah buah dari iman yang benar. Sementar itu, Shihab (2002, I: 88) mengartikan kata takwa dengan menghindar, yaitu (1) menghindar dari kekufuran dengan beriman kepada Allah, (2) berusaha melaksanakan segala perintah Allah dengan segenap kemampuan yang dimiliki dan menjauhi larangan-Nya, (3) menghindar dari segala aktivitas yang menjauhkan hati dan pikiran dari Allah SWT. Dengan demikian, kualitas iman terwujud dalam ketakwaan, sementara kualitas takwa seseorang, salah satunya adalah terlihat dari pelaksanaan ibadahnya kepada Allah SWT.

Data yang dihasilkan dari studi pendahuluan tersebut menunjukkan bahwa komitmen dalam melaksanakan ibadah mahasiswa yang menjadi setting penelitian masuk dalam katagori kurang baik. Ini artinya, bahwa perlu upaya yang signifikan dalam menstimulasi mahasiswa agar mempunyai motivasi untuk meningkatkan kuantitas dan kualitas ibadah mereka. Ini penting, karena ibadah dalam sistem religiusitas Islam mempunyai posisi sentral, dan bahkan besar pengaruhnya dalam mebentuk perilaku yang baik. Tentang ibadah shalat, misalnya, Allah berfirman:

Bacalah apa yang telah diwahyukan kepadamu, yaitu al-Kitab (al-Quran) dan dirikanlah shalat. Sesungguhnya shalat itu mencegah dari (perbuatanperbuatan) keji dan mungkar. Dan sesungguhnya mengingat Allah (shalat) adalah lebih besar (keutamaannya dari ibadat-ibadat yang lain). Dan Allah mengetahui apa yang kamu kerjakan (QS. Al-Ankabut: 45).

Pentingnya bimbingan ibadah dalam konteks peningkatan religiusitas mahasiswa juga terkait dengan pengaruh yang dihasilkan dari pelaksanaan ibadah tersebut. Dalam penelitian yang dilakukan oleh Widyayanti (2012: 111) bahwa terdapat hubungan yang signifikan antara pelaksanaan shalat dzuhur berjamaah dan shalat dhuha berjamaah terhadap perilaku sosial remaja. Ini artinya, bahwa ibadah, utamanya shalat yang dilakukan secara berjamaah dapat dijadikan sarana untuk meningkatkan keterampilan sosial. Pengaruh ibadah terhadap perilaku sosial 
yang lain juga diungkapkan oleh Zulkarnaini (2014). Dalam penelitian yang dilakukan menunjukkan bahwa wirid pada remaja mempunyai dampak terhadap perubahan perilaku sosial remaja peserta wirid remaja, baik perilaku terhadap orang tua, guru maupun perilaku terhadap masyarakat lingkungan di mana generasi muda tersebut berdomisili, walupun diakuinya, dampak tersebut belum terlalu signifikan.

Temuan penelitian yang menggambarkan kerendahan pelaksanaan ibadah di kalangan mahasiswa, merupakan sesuatu yang membawa kerawanan dilihat dari sisi kesehatan mental, karena secara empiris telah dibuktikan bahwa salah satu jenis ibadah dalam sistem religiusitas Islam, puasa misalnya, membawa dampak yang luar biasa dalam kesehatan mental pelakunya. Pembuktian pernyataan ini adalah beberapa hasil penelitian yang dikutip oleh Kurnanto (2010) sebagai berikut: (1) Penelitian Nicolayev, seorang guru besar yang bekerja pada lembaga psikiatri Moskow (the Moskow Psychiatric Institute), mencoba menyembuhkan gangguan kejiwaan dengan berpuasa. Dalam usahanya itu, ia menterapi pasien sakit jiwa dengan menggunakan puasa selama 30 hari. Nicolayev mengadakan penelitian eksperimen dengan membagi subjek menjadi dua kelompok sama besar, baik usia maupun berat ringannya penyakit yang diderita. Kelompok pertama diberi pengobatan dengan ramuan obat-obatan. Sedangkan kelompok kedua diperintahkan untuk berpuasa selama 30 hari. Dua kelompok tadi dipantau perkembangan fisik dan mentalnya dengan tes-tes psikologis. Dari eksperimen tersebut diperoleh hasil yang sangat bagus, yaitu banyak pasien yang tidak bisa disembuhkan dengan terapi medik, ternyata bisa disembuhkan dengan puasa. Selain itu kemungkinan pasien tidak kambuh lagi selama 6 tahun kemudian ternyata tinggi. Lebih dari separoh pasien tetap sehat. (2) Penelitian yang dilakukan Alan Cott terhadap pasien gangguan jiwa di Rumah Sakit Grace Square, New York juga menemukan hasil yang sejalan dengan penelitian Nicolayev. Pasien sakit jiwa ternyata bisa sembuh dengan terapi puasa. Puasa juga dapat digunakan untuk penyembuhan kecemasan, susah tidur, dan merasa rendah diri. Selain itu, menurut Hawari (2004: 251), puasa bisa berfungsi sebagai pengendalian diri (self control). Pengendalian diri adalah salah satu ciri utama bagi jiwa yang sehat, karena manakala pengendalian diri seseorang terganggu, maka akan timbul berbagai reaksi patologik (kelainan) baik dalam alam pikiran, perasaan, dan perilaku yang bersangkutan. Reaksi patologik yang muncul tidak saja menimbulkan keluhan subyektif pada diri sendiri, tetapi juga 
dapat mengganggu lingkungan dan juga orang lain.

Bukti empiris yang ditunjukkan oleh beberapa hasil penelitian di atas bisa berfungsi sebagai penguat, bahwa ibadah merupakan perintah Allah yang sangat fungsional dalam kehidupan manusia. Rajab (2013: 63) mengatakan bahwa ibadah dalam ajaran agama Islam merupakan pengokoh keyakinan dan penghidmatan manusia kepada Allah; menguatkan karakteristik disiplin diri dalam perannya sebagai wakil dan hamba Allah yang dipercaya oleh Tuhannya di muka bumu ini. Ibadah dalam Islam juga menjadi salah satu metode penyucian diri, baik dari aspek psikologis maupun dalam kehidupannya sehari-hari. Selain itu, menurut Rajab (2013: 64) psiko-spiritual ibadah melahirkan suatu sistem kejiwaan yang menghantarkan manusia untuk dekat dengan Tuhan, juga membawa manusia dalam kehidupan sosial yang penuh dengan rasa damai, tenang dan tentram. Hal ini dihasilkan dari fungsi ibadah yang memberikan latihan-latihan rohani yang aplikatif dan terjadual secara rutin seperti shalat, puasa dan beberapa ibadah lainnya.

Kualitas religiusitas seseorang, selain dibuktikan dari kekokohan iman dan kekuatan takwa, juga harus diwujudkan dengan kualitas amal shalehnya. Dalam alQuran, kata iman selain dirangkai dengan kata takwa, juga sering dirangkai dengan kata amal shaleh, bahkan jumlah lebih banyak, yaitu tak kurang dari 36 tempat (QS. 2: 82, 2: 227, 3: 57, 4: 57, 4: 173, 5: 9, 10: 4, 10: 9, 11: 23, 13: 29, 14: 23, 18: 30, 18: 88, 18: 107, 19: 60, 19: 96, 20: 82, 22: 56, 26: 227, 28: 80, 29: 7, 29: 9, 30:15, 30: 45, 31: 8, 32: 19, 34: 37, 35: 7, 40: 58, 42: 22, 42: 23, 47: 12, 84: 25, 95: 6, 98: 7, 103: 3). Amal shaleh, dalam perwujudannya dalam kehidupan seorang muslim, salah satunya adalah dalam bentuk al-akhlak al-karimah.

Temuan studi pendahuluan yang mengkatagorikan religiusitas mahasiswa sebelum ditreatmen pada posisi rendah juga mengindikasi rendahnya kualitas mereka dalam mengaplikasikan akhlak karimah dalam kehidupan sehari-hari. Padahal, akhlak mempunyai kedudukan yang sangat tinggi dalam ajaran agama Islam. Hal ini seperti terungkap dalam salah satu hadits Nabi Muhammad SAW yang menggambarkan bahwa salah satu misi diutusnya beliau oleh Allah SWT adalah untuk memperbaiki akhlak umat manusia:

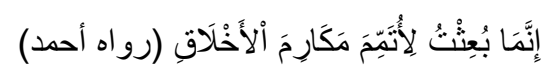

Artinya: "Bahwasanya aku diutus (oleh Allah) untuk menyempurnakan keluhuran akhlak (Budi pekerti)" (HR. Ahmad).

Misi khusus yang diberikan oleh Allah terhadap Nabi Muhammad SAW ini menggambarkan bahwa Islam menginginkan kehidupan dunia ini diwarnai 
oleh masyarakat yang berakhlak mulia. Hal ini ditekankan, karena selain membawa kebaikan dalam kehidupan individu, akhlak mulia yang dilakukan secara bersamasama dalam sebuah masyarakat juga akan membawa kebaikan dari masyarakat tersebut. Bahkan bagi pelakunya juga akan mendapat kehidupan yang bahagia kelak di akhirat. Allah SWT berfirman:

Artinya: Barangsiapa yang mengerjakan amal saleh, baik laki-laki maupun perempuan dalam keadaan beriman, maka sesungguhnya akan kami berikan kepadanya kehidupan yang baik dan sesungguhnya akan kami beri balasan kepada mereka dengan pahala yang lebih baik dari apa yang telah mereka kerjakan.

Selain itu, akhlak juga mempunyai pengaruh yang besar kelak ketika manusia menghadapi peradilan Allah SWT. Dalam sebuah hadits yang diriwayatkan oleh AlTirmidzi dikatakan bahwa akhlak yang baik akan memberatkan timbangan kebaikan seseorang nanti pada hari kiamat. Rasulullah SAW bersabda:

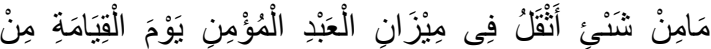

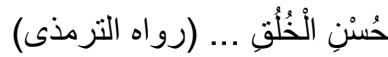

Artinya: "Tidak ada satupun yang akan lebih memberatkan timbangan (kebaikan) seorang hamba mukmin nanti pada hari kiamat selain dari akhlak yang baik." (HR. Turmudzi)

Selain fungsi dan kedudukan akhlak kaitannya dengan nilai eskatologis di atas, akhlak juga sangat fungsional dalam konteks kehidupan duniawi. Menurut Glock dan Stark (Kurnanto, 2014) menyebutkan bahwa semakin tinggi komitmen beragama pada aspek ritualistik (ibadah) seseorang, maka akan lebih mudah dalam mengimplementasikannya berupa pembentukan manusia berkarakter, dimana menurut Ardiansyah (2003) manusia berkarakter itu sendiri adalah manusia yang hidupnya senantiasa digerakkan oleh nilai-nilai kemanusiaan, seperti integritas, kerendahan hati, kesetiaan, pengendalian diri, kesabaran dan sebagainya. Sementara, karakter itu sendiri dalam konteks tertentu sering disamakan dengan akhlak. Dengan demikian, peningkatan pelaksanaan ritualistik dalam kehidupan beragama, maka akan semakin mempercepat proses pembentukan masyarakat yang berakhlak. Hal ini sama dengan apa yang diuraikan oleh Quthb (2003, VII: 212-213) bahwa balasan dari orang yang beramal shaleh adalah penghidupan yang baik (hayatan thayyiban) di dunia. Penghidupan yang baik ini bentuknya tidak harus dengan melimpahnya harta benda, tetapi bisa dalam bentuk pemerolehan kualitas hidup yang tenang, aman dan tentram, karena selalu dalam penjagaan dan perlindungan Allah.

Terkait dengan kedudukan akhlak dalam ajaran agama Islam, Sauri (2011: 15) menyebutkan bahwa akhlak adalah dimensi ketiga dari ajaran Islam setelah aqidah dan syari'ah. la adalah suatu ajaran yang menyangkut masalah-masalah 
kehidupan yang berkaitan dengan ketentuan-ketentuan dan ukuran baik buruk atau benar salahnya suatu perbuatan. Akhlak adalah manisfestasi dari tauhid dan amal shaleh. Dengan karakteristik akhlak seperti itu, maka dapat dikatakan bahwa akhlak dalam ajaran Islam merupakan aktualisasi diri seorang muslim, yang di dalamnya menyangkut konteks ketuhanan dan kemanusiaan. Akhlak adalah suatu prinsip kehidupan yang bersumber dari nilai-nilai yang diturunkan dari Sang Pencipta dan telah dicontohkan oleh sosok manusia yang sengaja didatangkan oleh Allah SWT sebagai figur manusia terbaik, yaitu manusia berbudi pekerti agung, Rasulullah SAW.

Berdasarkan pada temuan studi pendahuluan (pratest), juga dikaitkan dengan berbagai alasan betapa pentingnya religiusitas dalam membentuk kehidupan bermasyarakat yang sesuai dengan kehendak Tuhan Yang Maha Esa di kalangan mahasiswa, menunjukkan perlunya suatu penanganan yang tepat untuk membantu meningkatkan kualitas religiusitas pada mahasiswa dalam berbagai dimensi-dimensinya. Dengan upaya ini diharapkan mahasiswa dapat menjalani peran dan kewajibannya dengan tetap berada pada jalur kehidupan yang benar, sehingga berbagai fenomena kenakalan di kalangan mahasiswa, juga berbagai kecurangan dalam dunia pendidikan dapat dikurangi, syukur jika bisa dihilangkan sama sekali. Dalam kaitan ini, penangan yang peneliti tawarkan adalah dengan memaksimalkan proses pembelajaran ilmu tasawuf yang peneliti ampu selama ini.

Upaya yang peneliti lakukan, walaupun tidak menutup kemungkinan juga ada faktor lain, ternayata mampu meningkatkan religiusitas mahasiswa. Berdasarkan hasil analisis data diperoleh rata-rata total skor pretest sebesar 352,78 dengan simpangan baku sebesar 9,237 dan standar error sebesar 1,962, sedangkan rata-rata total posttest adalah sebesar 439,44 dengan simpangan baku sebesar 9.502 dan standar error sebesar 1,025. Dengan data tersebut terbukti bahwa pembelajaran ilmu tawsawuf mampu meningkatkan religiusitas mahasiswa, yaitu dengan peningkatan rata-rata sebesar 86.66 .

\section{G. Kesimpulan}

Berdasarkan pada paparan dan pembahasan di atas, peneliti mengambil kesimpulan sebagai berikut:

1. Religiusitas mahasiswa Fakultas Usihuluddin, Adab dan Dakwah IAIN Pontianak sebelum mendapatkan perlakuan dengan pembelajaran ilmu tasawuf secara umum berada pada katagori kurang baik. 
2. Religiusitas mahasiswa Fakultas Usihuluddin, Adab dan Dakwah IAIN Pontianak setelah mendapatkan perlakuan dengan pembelajaran ilmu tasawuf mengalami peningkatan dan berada pada katagori baik.

3. Pembelajaran ilmu tasawuf terbukti secara signifikan efektif meningkatkan religiusitas mahasiswa.

\section{H. Saran dan Rekomendasi}

Berdasarkan pada kesimpulan penelitian, peneliti memberikan beberapa saran dan rekomendasi sebagai berikut:

\section{Saran-saran}

a. Disarankan kepada sesama dosen di IAIN Pontianak agar dapat memaksimalkan proses pembelajaran yang dilakukan, yang tidak saja mengarahkan pada pencapaian hasil belajar berupa nilai mahasiswa, akan tetapi lebih diarahkan pada pembentukan karakter mahasiswa.

b. Kepada mahasiswa disarankan agar mengikuti emua proses pembelajaran dengan optimal, sehingga hasil belajarnya juga akan maksimal, yang tidak saja berupa nilai yang tinggi, akan tetapi juga diikuti oleh tingginya kualitas religiusitas mereka masing-masing. a. Kepada peneli berikutnya, agar melakukan penelitian dengan melibatkan populasi yang lebih besar, sehingga validitas eksternalnya semakin meyakinkan.

b. Kepada Fakultas Ushuluddin, Adab dan Dakwah IAIN Pontanak, agar mendorong pada dosen melakukan penelitian serupa yang melibatkan mata kuliah yang diampunya masingmasing.

\section{Daftar Pustaka}

Al-Qur'an.

Al-Ghazali. (2002). Manajemen Hati. Terjemahan. Surabaya: Pustaka Progresif.

Al-Ghazali. (2002). Metode Menaklukkan Jiwa Persfektif Sufistik. Bandung: Mizan.

Al-Ghazali. (1999). Mengobati Penyakit Hati. Bandung: Kharisma.

Abdurrahim, I. (1982). Kuliah Tauhid. Bandung: Pustaka.

Abdurrahim, I. (1990). Sikap Tauhid dan Motivasi Kerja. Dalam Ulumul Qur'an, Vol. II.

Ancok, D. dan Suroso. (2011). Psikologi Islami, Solusi Islam atas Problemproblem psikologi. Cet. VIII. Yogyakarta: Pustaka Pelajar.

\section{Rekomendasi}


Anshari, E.S. (1983). Kuliah Al-Islam, Pendidikan Agama Islam di Perguruan Tinggi. Bandung: Pustaka Anwar, R dan Solihin, M. (2000). IImu Tasawuf. Bandung: Pustaka Setia.

Campbell, D.T. dan Stanley, J.C. (1963). Experimental and Quasy Experimental Design for Research. Boston: Houghton Mifflon Co.

Frager, R. (2002). Psikologi Sufi untuk Transformasi Hati, Diri dan Jiwa. Jakarta: Serambi.

Ginanjar Agustian, Ary. (2000). Rahasia Sukses Membangun Kecerdasan Emosi dan Spiritual, ESQ Emotional Spiritual Quotient. Berdasarkan 6 Rukun Iman dan 5 Rukun Islam. Jakarta: Arga.

Haeri, F. (1998). Belajar Mudah Tasawuf. Jakarta: Lentera.

Hassan, R. (2006). Keragaman Iman, Studi Komperatif Masyarakat Muslim. Jakarta: Rajawali Press.

Haryanto, S. (2003). Psikologi Shalat, Kajian Aspek-aspek Psikologis Ibadah Shalat. Yogyakarta: Pustaka Pelajar.

Hawari, D. (1999). Al-Qur'an IImu Kedokteran Jiwa dan Kesehatan Jiwa, Yogyakarta: Bina Bhakti Prima Yasa.

Jalaluddin. (2002). Psikologi Agama, Edisi Revisi. Jakarta: Raja Grafindo Persada.
Kuntowijoyo. (1991). Paradigma Islam; Interpretasi Untuk Aksi. Bandung: Mizan.

Kurnanto, M.E. (2010). Konseling Islam, mengungkap nilai-nilai konseling dalam Al-Quran. Pontianak: STAIN Pontianak Press.

Kurnanto, M.E. (2014). Pengembangan Religiusitas Siswa dengan Model Bimbingan Berbasis Surah AlFathah. Sekolah Pascasarjana UPI Bandung. Disertasi. Tidak diterbitkan. Mustofa, H.A. (1997). Akhlak Tasawuf. Bandung: Pustaka Setia.

Najati, M.U. (1982). Al-Quran dan IImu Jiwa. Terj. Ahmad Rofi. Bandung: Pustaka.

Purwanto, S. (2011). Terapi Do'a. [Online]. Tersedia: (https://kotamedan. wordpress.com/category/terapi-doa/) [20 desember 2012].

Quthb, S. (2003) Tafsir fi Zhilâlil Quran, di Bawah Naungan al-Quran. Jilid I. Cet. I-XI. Jakarta: Gema Insani Press.

Rajab, K. (2013). Psikologis Agama. Yogyakarta: Aswaja Pressindo.

Rakhmat, J. (2003). Psikologi Agama, Sebuah Pengantar. Bandung: Miszan Rahmawati, S.U. (2014). Pengaruh Puasa terhadap Kesehatan Mental. Online. Tersedia:

http://www.masjidrayavip.org/index.p hp?option=com_content \&view=article\&id=79:pengaruh- 
puasa-terhadap-kesehatan-

mental\&catid=65:dra-siti-uriana-

rahmawati-fuad-ma\&ltemid $=104 \quad[6$

Mei 2014]

Sari, Y., Fajri, Rd. A dan Syuriansyah, T. (2012). Religiusitas pada Hijjabers Comunity Bandung. Hasil Penelitian. [Online].

Tersedia:

http://prosiding.lppm.

unisba.ac.id/index.php/sosial/article/d ownload/ 349/pdf [7 Mei 2013].

Sauri. S. (2011). Filsafat dan Teosofi Akhlak, Kajian Filosofis dan teosofis tentang Akhlak, Karakter, Nilai, Moral, Etika, Budi Perkerti, Tatakrama, dan Sopan Santun. Bandung: Rizki Press

Shihab, M.Q. (1998). Wawasan AI-Qur`an. Tafsir Maudhu'i atas Pelbagai Persoalan Umat. Bandung: Mizan.

Shihab, M.Q. (2010). Tafsir al-Mishbâh. Volume ke-1. Cet. III. Jakarta: Lentera Hati.

Shihab, M.Q. (2010) Tafsir al-Mishbâh.

Volume ke-6. Cet. III. Jakarta: Lentera Hati.

Simuh, dkk. (2001). Tasawuf dan Krisis. Yogyakarta: Pustaka Pelajar.

Siregar, R. (1999). Tasawuf dari Sufisme Klasil ke Neo-Sufisme. Jakarta: Rajawali.

Syukur, A. (1999). Menggagas Tasawuf. Yogyakarta: Pustaka Pelajar.
Tasmara, T. (2001). Kecerdasan Ruhaniah

(Trancendental Intelligence). Jakarta: Gema Insani Press.

Widiyanti, F. (2012) Pengaruh Intenitas Pelaksanaan Shalat Dzuhur dan Dhuha secara Berjamaah terhadap Perilaku Sosial Siswa di SMA Negeri 3 Salatiga Tahun 2012. Jakarta: Skripsi UIN Jakarta. Tidak Diterbitkan.

Yusuf LN, S. (2001). Psikologi Perkembangan Anak \& Remaja. Bandung: Remaja Rosdakarya.

Zainuddin, S. (2004). Metode Revolusi Qalbu Menuju Negeri Akhirat. Terjemahan. Jakarta: Kalam Mulia.

Zulkarnaini. (2014) Dampak Wirid Remaja terhadap Perubahan Nilai-nilai Ubudiyah dan Prilaku Sosial Generasi Muda di Kota Padang. Online. Tersedia: http://lppbifiba.blogspot.com/2009/02/dampakwirid-remaja-terhadap-perubahan. html [6 Mei 2014]. 